\title{
STUDENTS' CHOICE OF HIGHER EDUCATIONAL INSTITUTES; ANALYSIS OF FACTORS IN THE SRI LANKAN CONTEXT
}

\author{
Somaratna B. M. P. \\ The Open University of Sri Lanka
}

\begin{abstract}
Over the years national university intake in Sri Lanka has become increasingly competitive due to the increasing demand for higher education. Successive governments have tried to almost annually increase the number of national universities and the student intake but failed to cater to this demand. Therefore, those who fail to obtain access to state university education and those who complete the advanced level in the British curriculum have to seek admission to Fee Levying Higher Education Institutes (FLHEIs) in Sri Lanka due to the high cost of overseas education. Fee Levying Higher Education Institutes (FLHEIs) affiliated to foreign universities realizing the need to compete with each other offer international degrees in order to attract students. So the decision making process has become even more complex for the students. Data for this study was randomly collected from 1000 numbers of current students of Fee Levying Higher Education Institutes (FLHEIs) in the Western Province, Sri Lanka. A questionnaire was administered. The questions were categorized according to the conceptual framework developed based on the literature review. The data was analyzed using computer-based software packages. The results of this study can be helpful to Sri Lankan Fee Levying Higher Education Institutes (FLHEIs) in optimizing student intake.
\end{abstract}

Keywords- Fee Levying Higher Education Institutes (FLHEI), Students' Choice, Decision Making Process

\section{INTRODUCTION}

Sri Lanka has had a long history of education which runs back to several thousands of years. With the introduction of Buddhism from India in the $3^{\text {rd }}$ century BC, the ancient Indian education system influenced our education. Pirivena education became important both for the Buddhist Bhikkus and the laity. They studied the Dhamma as well as other necessary secular subjects in these pirivenas. The pirivena education system flourished till about the Kotte period and several descriptions of these in the Sandesha Kavyas tell us about the size, standards maintained and the nature of the education provided which served well the needs of the nation at the time. However, with the coming of the Portuguese the Dutch and the British who came in for trade but later colonized our country education came to be used as a tool for conversion to their religion - Christianity. For about 400 years we were under these western powers who occupied the maritime provinces first but later went into the central parts of the country as well. Missionary schools came to be established and the education system evolved as a means for proselytization. The system became more complex with the establishment of fee levying schools.

Then came the Buddhist revival and the nationalist movement for Independence which gradually became more active with the influence of Mahatma Gandhi's movement for Indian independence. One of the main achievements of the movement was the C. W. W. Kannangara Reform in 1945. Education was to be free and was recognized as a fundamental right. All Central schools (Madya Maha Vidyalayas) provided access to higher education and this paved the way for social mobility. With the gaining of Independence in 1948, more and more children gained entry to higher government jobs and there was a great demand for higher education. The literacy rate in Sri Lanka improved. Today it is more than $92 \%$ of the population. Several educational reforms were undertaken during the period after Independence. With the idea of making education standards equal to all the children, schools were taken over in the 1970 's by the state. However here too some schools opted to stay back as private schools and with time the complexity of the education system grew again. Today we have in Sri Lanka - government schools, assisted schools and fee levying schools. More and more private fee levying schools have come up with the idea of preparing students for London \& Cambridge examinations which also helps them to enter higher education institutes in other countries.

University education is more than the next level in the learning process. It is a critical component of human development and provides high level skills necessary for every labour market. Knowledge and application have become major factors in economic development. Hence students' choice and decision making in higher education has gained greater importance because higher education has become competitive and market oriented. Higher education enables individuals to expand their knowledge and skills, express their thought clearly, grasp abstract concepts and theories and increases their understanding of the world and their community. University education helps economic development of the country. 


\section{International Journal of Engineering Applied Sciences and Technology, 2020 \\ Vol. 5, Issue 8, ISSN No. 2455-2143, Pages 9-14 \\ Published Online December 2020 in IJEAST (http://www.ijeast.com)}

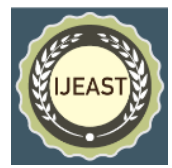

Developing Sri Lanka as a knowledge hub of Asia is a key development strategy of the government. The capacity of the state education system is limited and not more than $20 \%$ of the students' who qualify for university education gain admission to state universities. Hence the government has already commenced formulation of necessary legislation to regulate private sector higher education institutes in Sri Lanka. In a commercialized economy, with the intention of attracting the highest number of incoming students' higher educational institutes must operate in a similar manner as businesses and corporations. Since many factors are involved it is not easy to understand students' choice. Knowing the preference of students and the factors involved has become increasingly crucial for higher education institutes.

The history of university education in Sri Lanka goes back to the establishment of the University of Ceylon in Colombo in 1942 by the amalgamation of two reputed institutions, namely the Ceylon Medical College (Established in 1870) and the Ceylon University College (Established in 1921).

Today in Sri Lanka there are 15 state universities which function under the purview of the University Grants Commission (UGC). Undergraduate students are admitted to these Universities through a common examination, namely the General Certificate of Education (GCE) Advanced Level examination conducted by the Department of Examinations, and a selection procedure conducted by the UGC. Besides the above universities, there are three other governmentcontrolled Universities, namely the University of Buddhist and Pali Studies, the Kotelawala Defence University, and the University of Vocational Technology (UNIVOTEC), which are not under the UGC.

In Sri Lanka, admission to government (under the purview of UGC) Universities is highly competitive and the system has several barriers that hinder access of students to higher education. Each year several hundred thousand students sit for the GCE (A/L) examination, and around 50\%-60\% of them qualify for admission to universities. However, since the number of available places are limited, a very small number get selected for admission. In 2018 out of the total number of students who sat for the GCE (A/L), $64.40 \%$ got qualified for admission to universities. Out of the total qualified only $19.25 \%$ managed to secure a place in a university due to the lesser number of places available.

It is generally accepted that higher education should be made available to all those who aspire to it. This could be achieved by broadening the opportunities to allow the students to enter higher education institutes. In recent times there were a number of new government Universities and higher educational institutes established. The main objective behind establishing new Universities/Higher Education Institutes is to increase opportunities for higher education and diversify higher education. The university intake which was confined to about 12,000 students some years back has now increased up to about 30,000 as a result of establishing new universities and faculties.

Institutions offering degrees and diplomas outside the purview of the UGC are a recent development in the field of higher education in Sri Lanka. Some of these institutions are affiliated to foreign universities while others are based locally and function independently. Apart from the Higher Education Institutions mentioned above, there are certain local institutions which have been given permission by the UGC to conduct certain courses of study and offer degrees.

The Open University of Sri Lanka (OUSL) which is under the UGC functions independently to accommodate those who desire to undertake courses available through the open and distance learning (ODL) mode at a fee. The distance mode of Higher Education is widely expanding and accepted globally. The OUSL has introduced courses in the ODL mode in a number of key disciplines. It has now gained sufficient recognition both locally and within the South Asian region.

At the end of year 2017 there were 16 non state fee levying higher education institutes (NSHEI) offering 99 accredited local degree programmes (CBSL, 2017) At present selecting a higher educational institute has become strategically complicated due to optionality and flexibility of the programmes offered.

\section{LITERATURE REVIEW}

Students' choice criteria in selecting a higher education programme in various disciplines or an institution have been widely researched in several countries. The basic idea is that students and their parents (consumers) will choose a higher education programme and fee levying higher educational institute that matches their selection criteria academically, financially, and socially (Fernandez 2010). Many students on "student decision making" rely on economics and sociological theoretical frameworks to examine factors of students' choice (Jackson 1978: Tierney 1983 Hearn 1984 Somers et al; 2006). These studies analyze students' behavior as consumers in the fee levying higher education marketplace when pursuing higher education. However influential factors found in previous other studies varied among countries and the types of educational programmes in various disciplines.

Findings of researchers in this field can broadly be classified into five categories of factors; Economic, Social, Personal, Marketing and Higher Education Institute related. However, as Orasanu \& Connolly (1993) point out, the process of decision marking is one of "the most complex mechanisms of human thinking since various personal and environmental 


\section{International Journal of Engineering Applied Sciences and Technology, 2020 \\ Vol. 5, Issue 8, ISSN No. 2455-2143, Pages 9-14 \\ Published Online December 2020 in IJEAST (http://www.ijeast.com)}

factors and courses of action intervene with different results". Halpern (1997) says that students follow several steps to arrive at a decision on which higher education institute to join; a) realizing the necessity to make a decision, b) determining the goals to be achieved, c) generating alternatives that lead to attaining the proposed goals, d) evaluating whether the alternatives meet one's expectation, and e) selecting the best alternative.

Hossler Schmit \& Vesper (1999) point out that most studies that attempted to explain students' choice could be included in one of the following three categories, economic models, status attainment (sociological) models and combined models. The economic models center on the economic assumptions that prospective students are rational actors and make a careful cost-benefit analysis when choosing a higher education programme from fee levying higher education institutes (Hossler et al 1999). The sociological models (or status attainment models) concentrate on the importance of students' background characteristics and socio-economic status as factors affecting his choice of higher education. The combined model incorporates the characteristics of the economic and status attainment models to describe students' choice process (McDonough, 1997). Further combined models offer more depth and perspective to the decisionmaking process (Hamrick \& Hossler 1996).

Recent researchers have also found marketing strategy as a strong determinant factor in the students' FLHEI choice process. This is because it creates awareness among prospective students which in turn will increase student enrolment of a given FLHEI. FLHEIs should maintain an attractive, friendly atmosphere and impress and attract prospective students. FLHEI's should keep social media updated with information regarding their courses, student activities, achievements, innovative developments and scholarships available. In this respect brochures, posters, newspapers and TV advertisements play an important part (Yamamoto 2006).

\section{METHODOLOGY AND DATA ANALYSIS}

Based on the literature review and the experience of the researcher a conceptual framework for the research was developed.

\section{Higher Education Institute Selection Process}

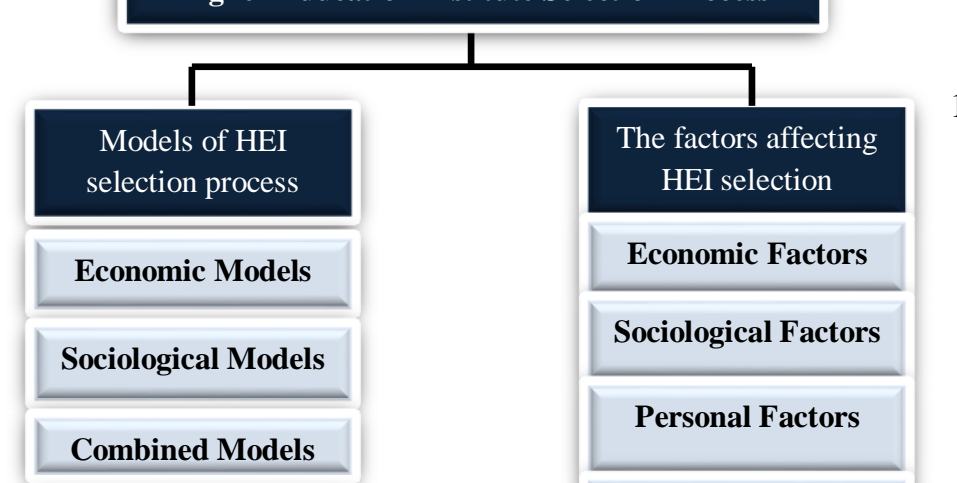

Figure 1 - Conceptual Model

The above factors have been divided into sub-categories as follows.

- Economic Factors include tuition fees, availability of scholarships, knowledge of future employment opportunities and ability to study while working.

- FLHEI related Factors include reputation of programme, reputation of institution, availability of accommodation facilities, specialized programmes offered, variety of courses offered, availability of sports activities, size of student population and student/professor ratio.

- Marketing related Factors include newspaper articles, visit to university and university publications.

- Personal Factors include plans for graduate work, location - easy access, closeness to home and preparation for graduate work

- Social Factors include influence of teachers, influence of father, influence of school mates, influence of mother, influence of friends, and influence of relatives/siblings.

For the study data was collected from 1000 numbers of current students of fee levying higher education institutes (FLHEIs) in the Western Province, Sri Lanka. Data was analyzed using computer-based software packages. $64 \%$ of the sample were male participants while only $36 \%$ were female participants. 


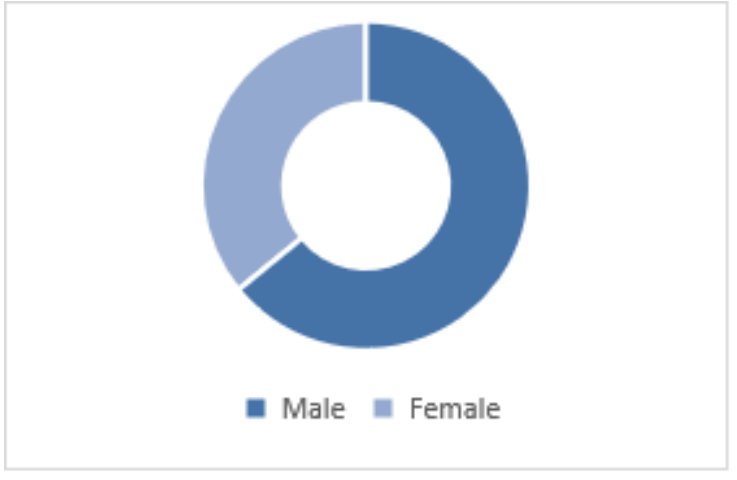

Figure 2 - Gender of Participants

Through this research the researcher tries to find out answers to the following questions.

1. What is the relative importance of each factor (subcategory) in the above categories?

2. What are the most significant factors that influence students' choice of FLHEI - Economic, Social, Personal, Marketing or HEI related Factors?

In order to find out answers to the above questions Chi square analysis and Cramers V Effect size together with the relative important index were carried out. The open-ended questions were analyzed using percentage analysis.

\section{ANALYSIS OF DATA}

The data was analyzed using computer-based software packages. In order to find out an answer to the first question whether the sub-categories within factors have the same importance in the FLHEI selection process or not, the data was analyzed using chi square analysis. Table 1 shows the results of the chi square analysis.

\begin{tabular}{|l|c|r|r|r|r|r|r|}
\hline $\begin{array}{c}\text { Factor } \\
\text { Categories }\end{array}$ & $\mathbf{N}$ & $\mathbf{X}^{\mathbf{2}}$ & $\mathbf{D F}$ & $\boldsymbol{\alpha}$ & $\mathbf{C R I T}$ & $\begin{array}{c}\text { Cramers } \\
\text { V Effect } \\
\text { Size }\end{array}$ & Rank \\
\hline $\begin{array}{l}\text { FLHEI related } \\
\text { Factors }\end{array}$ & 1000 & 668.235 & 7 & 0.05 & 14.07 & 0.3089 & 1 \\
\hline Social Factors & 1000 & 359.104 & 5 & 0.05 & 11.07 & 0.2680 & 2 \\
\hline $\begin{array}{l}\text { Economic } \\
\text { Factors }\end{array}$ & 1000 & 116.661 & 3 & 0.05 & 7.81 & 0.1972 & 3 \\
\hline $\begin{array}{l}\text { Personal } \\
\text { Factors }\end{array}$ & 1000 & 107.418 & 3 & 0.05 & 7.81 & 0.1892 & 4 \\
\hline $\begin{array}{l}\text { Marketing } \\
\text { related Factors }\end{array}$ & 1000 & 40.330 & 2 & 0.05 & 5.99 & 0.1421 & 5 \\
\hline
\end{tabular}

Table 1 - Chi Square analysis results and Cramers V Effect Size results

From the chi square analysis results we can see that the chi square values are more than critical values for all 5 categories. i.e. sub-categories within factors have different importance levels in the FLHEI selection process. The relative importance index was calculated to find out which factor (sub-category) was most significant. (Table 2, Figure 4)

\begin{tabular}{|l|c|c|}
\hline \multicolumn{1}{|c|}{ Factor } & $\begin{array}{c}\text { Relative } \\
\text { Importance } \\
\text { Index }\end{array}$ & Ranking \\
\hline Economic Factors & 0.8228 & 1 \\
\hline Tuition fees & 0.7792 & 2 \\
\hline Availability of scholarships & 0.7772 & 3 \\
\hline $\begin{array}{l}\text { Knowledge of future } \\
\text { employment opportunities }\end{array}$ & 0.7314 & 4 \\
\hline Ability to study while working & & \\
\hline FLHEI related Factors & 0.794 & 1 \\
\hline Reputation of programme & 0.7714 & 2 \\
\hline Reputation of institution & 0.6524 & 3 \\
\hline $\begin{array}{l}\text { Availability of accommodation } \\
\text { facilities }\end{array}$ & 0.6524 & 4 \\
\hline Specialized programmes offered & 0.6166 & 5 \\
\hline Variety of courses offered & 0.6132 & 6 \\
\hline Availability of sports activities & 0.582 & 7 \\
\hline Size of student population & 0.5112 & 8 \\
\hline Student/Professor ratio & & \\
\hline Marketing related Factors & 0.6546 & 1 \\
\hline Newspaper articles & 0.6384 & 2 \\
\hline Visit to university & 0.6132 & 3 \\
\hline University publications & & \\
\hline Personal Factors & 0.7476 & 1 \\
\hline Plans for graduate work & 0.7456 & 2 \\
\hline $\begin{array}{l}\text { Location - easy access by bus, } \\
\text { train }\end{array}$ & 0.7016 & 3 \\
\hline Closeness to home & 0.644 & 4 \\
\hline Preparation for graduate school & 0.8266 & 1 \\
\hline Social Factors & 0.7392 & 2 \\
\hline Influence of teachers & 0.7346 & 3 \\
\hline Influence of father & 0.6782 & 4 \\
\hline Influence of school mates & 0.584 & 5 \\
\hline Influence of mother & 0.5542 & \\
\hline Influence of friends & & \\
\hline Influence of relatives/siblings & & \\
\hline & & \\
\hline & & \\
\hline & & \\
\hline
\end{tabular}

Table 2 - Ranking of sub-categories based on the relative importance index

In order to find answer to the second question "Whether the factors have the same importance in the FLHEI selection process or not", Cramers V Effect Size was calculated and factors were ranked (Table 1, Figure 3). It was revealed that the most important factors were FLHEI related factors while Social, Economic, Personal and Marketing related factors gained $2^{\text {nd }}, 3^{\text {rd }}, 4^{\text {th, }}$ and $5^{\text {th }}$ places respectively. 


\section{International Journal of Engineering Applied Sciences and Technology, 2020 \\ Vol. 5, Issue 8, ISSN No. 2455-2143, Pages 9-14 \\ Published Online December 2020 in IJEAST (http://www.ijeast.com)}

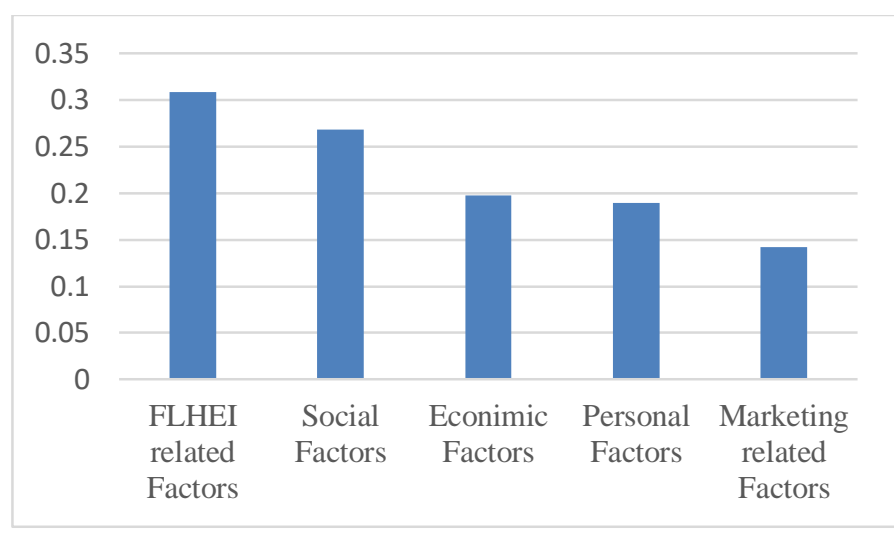

Figure 3 - Cramers V Effect Size of Categories

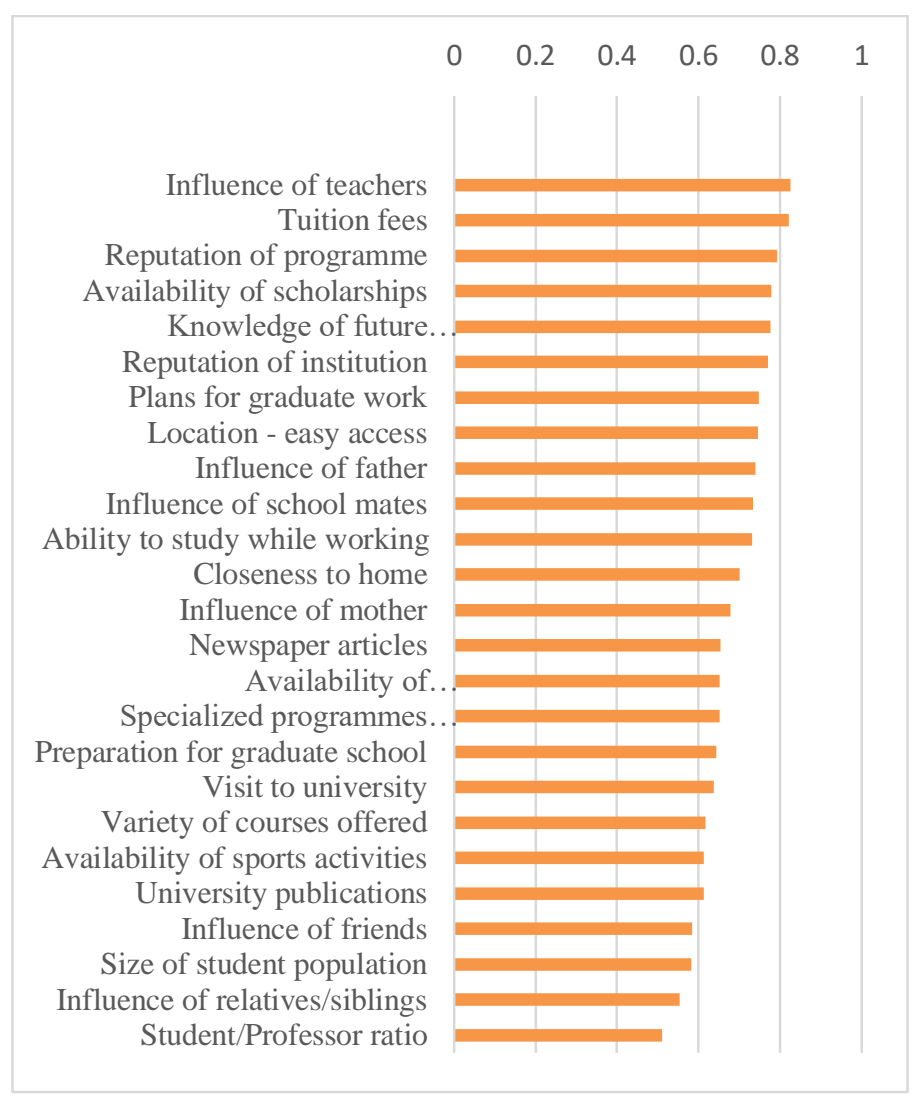

Figure 4 - Relative importance index

From the results it was revealed (Table 2, Figure 4) that the three most important economic factors are tuition fees, availability of scholarships and future employment opportunities. Among the FLHEI related factors the three most important factors are reputation of the programme, reputation of the institution and availability of accommodation facilities. The three most important marketing related factors in sequence are newspaper articles, visit to university and university publications. Plans for graduate work, location, and closeness to home are the three most important personal factors. Among the social factors, influence of teachers, father, and school mates were the three most important factors.

Answers to the open-ended questions have also revealed certain important findings. As revealed in the answers to the questions about the FLHEIs which accepted the students, it was found that $37 \%$ of them have been accepted to the most preferred FLHEI while $42 \%$ of them have been accepted to the second preferred FLHEI and $11 \%$ of them have been accepted to the third preferred FLHEI. 32\% of the students who were accepted to the FLHEI of their first choice were not attending the same FLHEI because the tuition fees were too high while $21 \%$ said they did not pass the selection test.

$44 \%$ of the students stated that they were attending the FLHEI they chose because of affordable tuition fees while for $32 \%$ it was advice that their teachers had given and $17 \%$ said the availability of scholarships made them go to the FLHEI they were attending. When asked how they feel about their FLHEI choice $31 \%$ of them stated that they were satisfied with their decision while $17 \%$ stated that they had some doubts.

\section{CONCLUSION AND RECOMMENDATIONS}

The decision-making process of selecting a FLHEI is very complex and involves a number of factors. Through this research the researcher tried to identify the major factors involved and the sequence of their importance. The results of this research would be useful to FLHEIs to develop strategies to attract more students.

According to this research the most important factors in making the FLHEI choice are FLHEI related factors. Social Factors are in the second place of importance. Economic Factors, Personal Factors, Marketing related Factors are in third, fourth and in fifth places respectively. However, when sub-categories were analyzed together, the most important sub-category was influence of teachers while tuition fees was in the second place. The reputation of the programme was in the third place. The FLHEIs should give more emphasis to FLHEI related factors and social factors over economic, marketing, and personal factors when developing their strategies to attract more students. Since influence of teachers and tuition fees shows the first two highest ranking subcategories when taken together, it should also be taken into consideration when developing strategies, together with other important factors based on the relative importance index. This research was carried out taking a sample of 1000 numbers of current students from FLHEIs in the Western Province, Sri Lanka only. To confirm the results a bigger sample from a wider area may be needed. The results may be 


\section{International Journal of Engineering Applied Sciences and Technology, 2020 \\ Vol. 5, Issue 8, ISSN No. 2455-2143, Pages 9-14 \\ Published Online December 2020 in IJEAST (http://www.ijeast.com)}

different in other parts of the country. So further research is necessary to validate the findings of this study.

\section{REFERENCES}

1) Abeygunawardena, K. A. V. (2018). Influential Factors in Selecting a Bachelor's Degree from Private Higher Educational Institutes in Sri Lanka A Study Based on Undergraduates of International Degree Programmes. PEOPLE: International Journal of Social Sciences, 4(2), (pp. 75-96). https://dx.doi.org/10.20319/pijss.2018.42.7596

2) Central Bank of Sri Lanka (2017). Annual Report. [Online] Available at: https://www.cbsl.gov.lk/en/publications/economicand-financial-reports/annual-reports/annual-report$\underline{2017}$

3) Fernandez, J. L. (2010). An exploratory study of factors influencing the decision of students to study at Universiti Sains Malaysia. Kajian Malaysia, 28(2), (pp. 107-136).

4) Halpern, D. F. (1997). Critical thinking across the curriculum: A brief Edition of Thought and Knowledge. ( $1^{\text {st }}$ Ed.). Mahwah, New Jersey: Lawrence Erlbaum Associates, Inc.

5) Hamrick, F. A., and Hossler, D. (1996). Diverse information-gathering methods in the postsecondary decision-making process. Review of Higher Education, 19(2), (pp. 179-198). https://doi.org/10.1353/rhe.1996.0029

6) Helgesen, O. (2008). Marketing for Higher Education: A relationship marketing approach. Journal of Marketing for Higher Education, 18(1), (pp. 50-78).

7) Hemsley-Brown, J., and Oplatka, I. (2006). Universities in a competitive global marketplace: A systematic review of the literature in higher education marketing. International Journal of Public Sector Management, 19(4), (pp. 316-338).

8) Hossler, D., Schmit, J., and Vesper, N. (1999). Going to college: How social, economic, and educational factors influence the decisions students make, Baltimore: Johns Hopkins University Press.

9) Jackson, G. A. (1978). Financial aid and student enrolment. The Journal of Higher Education, 49(6), (pp. 548-574). https://doi.org/10.2307/1981139
10) McDonough, P. M. (1997). Choosing colleges: How social class and schools structure opportunity. Albany: SUNNY Press.

11) Orasanu, J., \& Connolly, T. (1993). The reinvention of decision making. In G. A. Klein, J. Orasanu, R. Calderwood, \& C. E. Zsambok (Eds.), Decision making in action: Models and methods, 3-20, Westport, CT, US: Albex Publishing.

12) Shanka, T., Quintal, V., and Taylor, R. (2005). Factors influencing international students' choice of an education destination: A correspondence analysis. Journal of Marketing for Higher Education, 15, (pp. 31-46). https://doi.org/10.1300/J050v15n02_02

13) Somers, P., Haines, K., Keene, B., Bauer, J., Pfeiffer, M., McCluskey, J., \& Sparks, B. (2006). Towards a theory of choice for community college students. Community College Journal Research and Practice, 30(1), (pp. 53-67). https://doi.org/10.1080/10668920500248886

14) Tierney, M. L. (1983). Student college choice sets: Toward an empirical characterization. Research in Higher Education, 18(3), (pp. 271-284).

15) Yamamoto, G. T. (2006). University evaluationselection: A Turkish case, International Journal of Educational Management, 20(7), (pp. 559-569). 